\title{
CLIMATE IMPACT ON ORIGIN AND TOURISM VALORISATION OF TRADITIONAL URBAN ARCHITECTURE IN BOSNIA\&HERZEGOVINA AND CROATIA
}

\author{
Belmar Begić ${ }^{1}$
}

\begin{abstract}
Climate stands for one of the important factors of tourism valorisation in a certain area. For the purpose of this paper Köppen climatic classification has been used. In a given area distinguished types of climate include: temperate climate $\mathrm{C}$, continental climate $\mathrm{D}$ and alpine climate E. Considering the fact that climate can indirectly impact the geologic structure of certain areas on the Earth's surface by means of insolation and precipitation, building materials for architecture can be various. For example, as main or dominant building material in areas with warm climate types a stone is the most commonly used material, but wood and timber are commonly used in areas with cooler climate types. This research is based on selected urban areas for the each belonging climate type. By using Köppen climatic classification for the GIS mapping of climate subtypes, which are based on long-term climate data, selected urban areas have been chosen. Cities that belong to Csa climate subtype are: Mostar, Split and Dubrovnik, cities under Csb climate subtype include: Livno, Konjic and Rijeka, cities that belong to Cfa subtype include: Bijeljina, Osijek and Vukovar, cities under Cfb subtype include: Sarajevo, Banja Luka and Zagreb, towns that belong to Cfc climate include: Delnice and Slunj, and towns under Dfb climate subtype are: Kupres and Nevesinje. Areas with Dfc and ET climate subtypes include rural settlements and unpopulated wild areas. Research focuses on architecture from the six most significant historical periods: Antique, Byzantine, Medieval, Venetian, Ottoman and Austro-Hungarian. Based on all the characteristics described before, the conclusion implicates that climate factors have significant impact on the architectural styles, and generally on the urban environment which is the tourism valorisation object.
\end{abstract}

Key words: climate types, architecture, GIS, tourism, valorisation, Bosnia\&Herzegovina, Croatia

\section{GEOGRAPHIC LOCATION OF BOSNIA\&HERZEGOVINA AND CROATIA}

Territories of Bosnia and Herzegovina and Republic of Croatia in terms of regional geography are situated mostly in South-East Europe, and partly in Central Europe. By the contemporary political and geographical terms this area covers parts of the Western Balkans. Geospace of these two countries is located inside the next geographic coordinates: $42^{\circ} 24^{\prime} \mathrm{N}, 46^{\circ} 33^{\prime} \mathrm{N}$ and $13^{\circ} 30^{\prime} \mathrm{E}, 19^{\circ} 37^{\prime} \mathrm{E}$.

This area's main tectonic feature is situation at Alpine-Himalayan orogenic belt, that includes Dinaric Alps. Dinaric Alps mountain range is a natural zone that separates Pannonian and Adriatic basin. Those mountains were formed by orogenic folding movements. In terms of climate geography, this area is a transitional zone between subtropic and temperate climatic zones. Particular impact on the climate condition has the nearness of Mediterranean, that includes Adriatic sea as well. On the other hand, Pannoanian basin openness allows stronger penetration of cold air masses from the north. In this area main climate types by Koppen classification include: Cs type (Mediterranean climate), Cf types (temperate warm and maritime climates), Df types (hemiboreal climate) and ET type (alpine tundra climate). Natural barrier between $\mathrm{Cs}$ and Cf climate types is Df

\footnotetext{
${ }^{1}$ Master of Geography in the field of Tourism and Environmental Protection, Faculty of Science, University of Sarajevo, Sarajevo, Bosnia and Herzegovina.
} 
climate type, that covers the area of Dinaric Alps, hence their southern parts have Cs, but northern parts have $\mathrm{Cf}$ climate type. Hydrographic objects drain their waters into two drainage basins: Black sea basin (through rivers Sava and Danube) and Adriatic sea basin. The most important rivers that discharge into the Adriatic sea are: Raša, Zrmanja, Krka, Cetina, Neretva and Trebišnjica, while the Black sea basin backbone includes river Danube and it's large tributary rivers Drava and Sava which is the flow endpoint of these rivers: Kupa, Una, Vrbas, Bosna, Ukrina and Drina. This area's vegetation belongs to Palearctic biomes of Mediterranean forests, woodlands and scrub and Temperate broadleaf.

In terms of administrative structure, Republic of Croatia consists of lower taxonomic units - counties (Croatia has total 21 counties), while Bosnia\&Herzegovina consists of entities (Federation of $\mathrm{BiH}$, Serb Republic and Brčko District), and it's entity Federation of $\mathrm{BiH}$ is divided into 10 cantons. Last censuses provide data for total Croatian population of $4,284,889$ residents $^{2}$, and total population of Bosnia\&Herzegovina is 3,791,622 residents ${ }^{3}$. Settlements in this area are formed in river valleys, as well as in coastal areas, so the most significant among them are settlements with population over 100,000 and those settlements are dominant macroregional centers. In Croatia the most significant cities are Zagreb (790,001), Split $(178,102)$, Rijeka $(128,624)$ and Osijek $(108,048)$, while in Bosnia\&Herzegovina those cities are Sarajevo (391.130) and Banja Luka (150.997). Economy of Bosnia\&Herzegovina is based on different industries and services, so the most important export products include metals, machines, furniture, mineral products, footwear, chemical products, wood products and textile. The most important export trade destinations are Croatia, Germany, Italy, Austria and Slovenia, while the import destinations are Croatia, Germany, Serbia, Italy, Russia and Slovenia. In 2012 total country export trade was valued at 5.22 billion USD, and total import trade was valued at 9.93 billion USD. ${ }^{4}$ Economy of Croatia is based on different industries and services, especially on tourism. Croatian main export products include machines, mineral products, chemical products, vehicles and transportation parts, metal products, food products and textile. The most important Croatian export trade destinations are Italy, Bosnia\&Herzegovina, Germany, Slovenia and Austria, while the most important import trade destinations are Italy, Germany, China, Slovenia and Russia. In 2012 total country export trade was valued at 12.8 billion USD, and total import trade was valued at 20.3 billion USD. ${ }^{5}$ Bosnia\&Herzegovina is a member state of CEFTA group and NATO program Partnership for Peace, while Croatia is full member state of European Union and NATO alliance. Both countries are member states of Council of Europe and United Nations.

In terms of culture, both countries have various cultural and historical heritage. Bosnia\&Herzegovina has 2 UNESCO world heritage sites: Old Bridge area of the Old city of Mostar and Mehmed Paša Sokolović Bridge in Višegrad, while Croatia has 7 UNESCO sites: Historical complex of Split with the Palace of Diocletian, Old City of Dubrovnik, Plitvice lakes National Park, Euphrasian Basilica in the Historic center of Poreč, Historic city of Trogir, The Cathedral of St. James in Šibenik and Stari Grad plain on the Hvar island. $^{6}$

\footnotetext{
${ }^{2}$ Statistic bureau of Croatia

${ }^{3}$ Statistic bureau of Federation of $\mathrm{BiH}$

${ }^{4}$ https://atlas.media.mit.edu/en/profile/country/bih/(19.08.2015.)

${ }^{5} \mathrm{https}: / /$ atlas.media.mit.edu/en/profile/country/hrv/ (19.08.2015.)

${ }^{6} \mathrm{http}: / /$ whc.unesco.org/en/list/ (21.08.2015.)
} 


\section{URBAN ARCHITECTURE OBJECTS INVENTORY ACCORDING TO CLIMATE TYPES AND HISTORICAL PERIODS}

Urban architecture objects inventory is based on the six main historical periods and climate types by Koppen classification. According to Koppen the most significant climates include Mediterranean climate (Cs) with it's two subtypes Csa and Csb, temperate warm and maritime climate with it's two subtypes Cfa and Cfb and hemiboreal climate with it's Dfb subtype. The most significant historical periods where these objects belong include: Antique, Byzantine, Medieval, Venetian, Ottoman and Austro-Hungarian.

Label Cs stands for Mediterranean climate in terms of Koppen climate classification. Letter, $\mathbf{s}^{\text {" }}$ denotes summer period with dry weather conditions. The main Cs climate type can be differentiated due to the quantitative and spatial dinamics of average annual and monthly (July) isotherm lines. Therefore in this climate type two climate subtypes can be distinguished: Csa - Mediterranean climate with hot and dry summers and Csb Mediterranean climate with warm summers.

Label Cf stands for temperate warm i humid climate according to Koppen classfication. Letter , $\mathbf{f}^{\prime \prime}$ denotes conditions with almost even distribution of precipitation, which means there are no extremly dry periods in areas with $\mathrm{Cf}$ climates. Climate subtype Cfa has hot and dry summer conditions with mean air temperatures of the warmest month above $22^{\circ} \mathrm{C}$ (usually in July or August), while Cfb subtype has warm, but slightly cooler summer conditions, when the mean air temperatures is higher than $10^{\circ} \mathrm{C}$ in 4 months period nad the mean air temperature of the warmest month is below $22^{\circ} \mathrm{C}$.

Climate type Df in the area can be distinguished into two climate subtypes, according to average annual, January and July isotherm lines: subtype Dfb corresponds to hemiboreal climate with temperate humidity and warm summers, while subtype Dfc corresponds to hemiboreal climate with humid and cool summers. Climate subtype Dfc covers non-urban areas in Bosnia\&Herzegovina and Croatia, so it's not the subject of study in this paper.

\section{Architecture in the areas of Cs climate type}

In the areas of $\mathrm{Cs}$ climate type the main characteristics of traditional urban architecture depend mainly on geologic structure and climate impacts in certain area. This area's geologic structure consists dominantly of limestones, so the most objects have been built by that material, whereas dry conditions and sparse vegetation have caused very limited usage of wood material. Throughout history the expansions of past empires have deteriorated natural environment, especially in terms of deforstation with visible aftereffects even today.

The most significant monuments in cities with Csa climate subtype include:

Split:Diocletian's Palace (Antique period), Cathedral of Saint Domnius (Medieval period), Prokurative square (Austro-Hungarian period) ${ }^{7}$

Mostar: Basilica Cim (Antique period), The Old Bridge area, Karađoz-begmosque (Ottoman period), High school building (Austro-Hungarian period)

${ }^{7}$ http://www.visitsplit.com/en/446/attractions (24.08.2015.) 
Zadar: Church of Saint Donatus (Byzantine period), Cathedral of Saint Anastasia (Venetian period)

Šibenik:Cathedral of Saint James (Venetian period)

Dubrovnik:City walls with forts (Medieval perod), Sponza Palace, Church of Saint Blaise (Venetian period), Hilton Imperial Hotel $^{8}$ (Austro-Hungarian)

The most significant monuments in cities with Csb climate subtype include:

Livno:early Christian basilica (Antique period), Hajji Ahmet Dukatar mosque,Bali-aga Ljubunčić mosque, Lala-pasha mosque, Monastery church of Saints Peter and Paul in Gorica, Orthodox church, Duman old bridge (Ottoman period), High School building, Municipality old building, Water supply station $\operatorname{Duman}^{9}$ (Austro-Hungarian period)

Knin: Knin Fortress (Medieval period)

Konjic: Čaršija mosque, Old bridge (Ottoman period)

Poreč: Euphrasian basilica (Byzantine period)

Opatija: Kvarner Hotel (Austro-Hungarian)

Pula: Pula Arena, Arch of the Sergii (Antique period), Castle or Kaštel ${ }^{10}$ (Venetian period)

\section{Architecture in the areas of $\mathrm{Cf}$ climate type}

The conditions of $\mathrm{Cfa}$ and $\mathrm{Cfb}$ climate subtypes have allowed various building styles, wherein the main construction materials include stone (limestone), sand, lime plaster, wood material etc. The most numerous monuments originate from the Medieval, Ottoman and Austro-Hungarian period, while there are no representative monuments from Antique, Byzantine or Venetian periods.

The most significant monuments in cities with Cfa climate subtype include:

Osijek: Korogyvar Fortress (Medieval period), Fortified town of Osječka Tvrđa, Pejačević family's krypt, Counts Pejačević Palace (Austro-Hungarian period)

Vukovar: Historical Baroque City center, The Coach Post building, City Magistrate building, Central Pharmacy Kirchbaum-Švarc, Grand Hotel, Castle Eltz, Church of Saints Filip and Jakov and the Franciscan Monastery, Palace of the Syrmia County, Birth house of Lavoslav Ružička, Saint Rok's Chapel, Orthodox Church of Saint Nikolaj ${ }^{11}$ (AustroHungarian period)

Bijeljina: Atik mosque, Saint Georgije's church (Ottoman period), Building of the Assembly of the City, Old High School building (Austro-Hungarian period)

The most significant monuments in cities with $\mathbf{C f b}$ climate subtype include:

Zagreb: The Lotrščak Tower, The Stone gate, Medvedgrad Fortress, Saint Mark's Church, Cathedral of the Assumption of the Blessed Virgin Mary, Church of Saint Francis of Assisi

\footnotetext{
${ }^{8}$ Dubrovnik Tourist Board (2013) Dubrovnik Riviera Info, Alfa-2. Dubrovnik

${ }^{9}$ Burek, A. (2007) Kameno Hlivno, Livno u turskom vaktu (Stone Hlivno, Livno in the Ottoman time), Planjax. Tešanj

${ }^{10}$ Istria Tourist Board (2015) Enjoy Istra summer 2015, Radin Print. Sveta Nedelja

${ }^{11}$ http://www.turizamvukovar.hr/vukovar_eng.php?stranica=171(23.08.2015.)
} 
(Medieval period), Saint Blaise's church, Croatian State archives, Croatian National theater, Palace Hotel, Ilica street ${ }^{12}$ (Austro-Hungarian period)

Sarajevo: Ghazi Husrev-Bey's mosque, The Emperor's mosque, Baščaršija old town, The old orthodox church, Cathedral church of the Nativity of the Theotokos (also known as Serbian orthodox cathedral), The old Synagogue, Svrzo's house (Ottoman period), Ferhadija street, Ban Kulin alley, Bosnia\&Herzegovina Presidency building, Sarajevo Academy of fine arts, City Hall, City market (also known as Markthalle), Cathedral of Jesus' Heart, The National museum of Bosnia\&Herzegovina, Marijin Dvor city area, Europe Hotel (Austro-Hungarian period)

Banja Luka: Kastel or Castle fortress (Medieval period), Ferhadija mosque (Ottoman period), Mariastern Abbey, Bosna Hotel, City promenade Gospodska street, Museum of modern art of Republika Srpska (also known as The old railway station building) (AustroHungarian period)

\section{Architecture in the areas of Df climate type}

In the areas of Df climate type there are few urban zones, which are characterized by mixed types of urban-rural settlements. In the areas of Dfc climate subtype, there are only rural settlements, while in the areas of Dfb climate subtype exist urban zones with traditional architecture. Characteristics of Df climate subtype are very similar to the characteristics of Cf climate types on the northern slopes of Dinaric Alps, but also they are similar to Cs climate types of the southern slopes of Dinaric Alps. Higher areas of Dfb climate subtype due to the larger volume of snowfall anually, have objects with the high roof constructions and small windows.

The most significant monuments in cities with Dfb climate subtype include:

Glamoč:Basilica in Radaslije (Antique period), Old fortified town Glamoč (Ottoman period)

Kupres: Basilica in Otinovci (Antique period), Ruins of the Medieval church in Otinovci (Medieval period)

\section{TOURIST EVALUATION OF URBAN ARCHITECTURE OBJECTS BY HISTORICAL PERIODS}

Tourist evaluation (sometimes tourism valorisation) determines valuation, estimation or assessment for tourist attractions values, or assessment for tourist attractiveness all of the phenomena, objects or spaces which have attractive features interesting to tourists or visitors who can fulfill their recreational and/or cultural needs by visiting them. The most important method for tourism evaluation is combined qualitative and quantitative method of comparison. For tourist evaluation of cultural and historical monuments essential elements are: travel or tourist-geographic location, artistic value, surroundings value, tourist attractiveness and recognizability, fit-out of the visiting place, incorporation into tourist resources. Assessment is marked by numbers from 1 to 5 , where mark 1 means unsatisfying quality and such objects should not be presented, mark 2 means satisfying quality so the objects have local tourism significance, mark 3 means good quality so the objects have regional tourism significance, mark 4 is for very good quality which means

\footnotetext{
${ }^{12}$ Zagreb Tourist Board (2015) Step by step Zagreb: A walk through Zagreb, Kerschoffset. Zagreb
} 
the objects have wider regional or national tourism significance, and mark 5 means excellent quality so the objects have international tourism significance. ${ }^{13}$

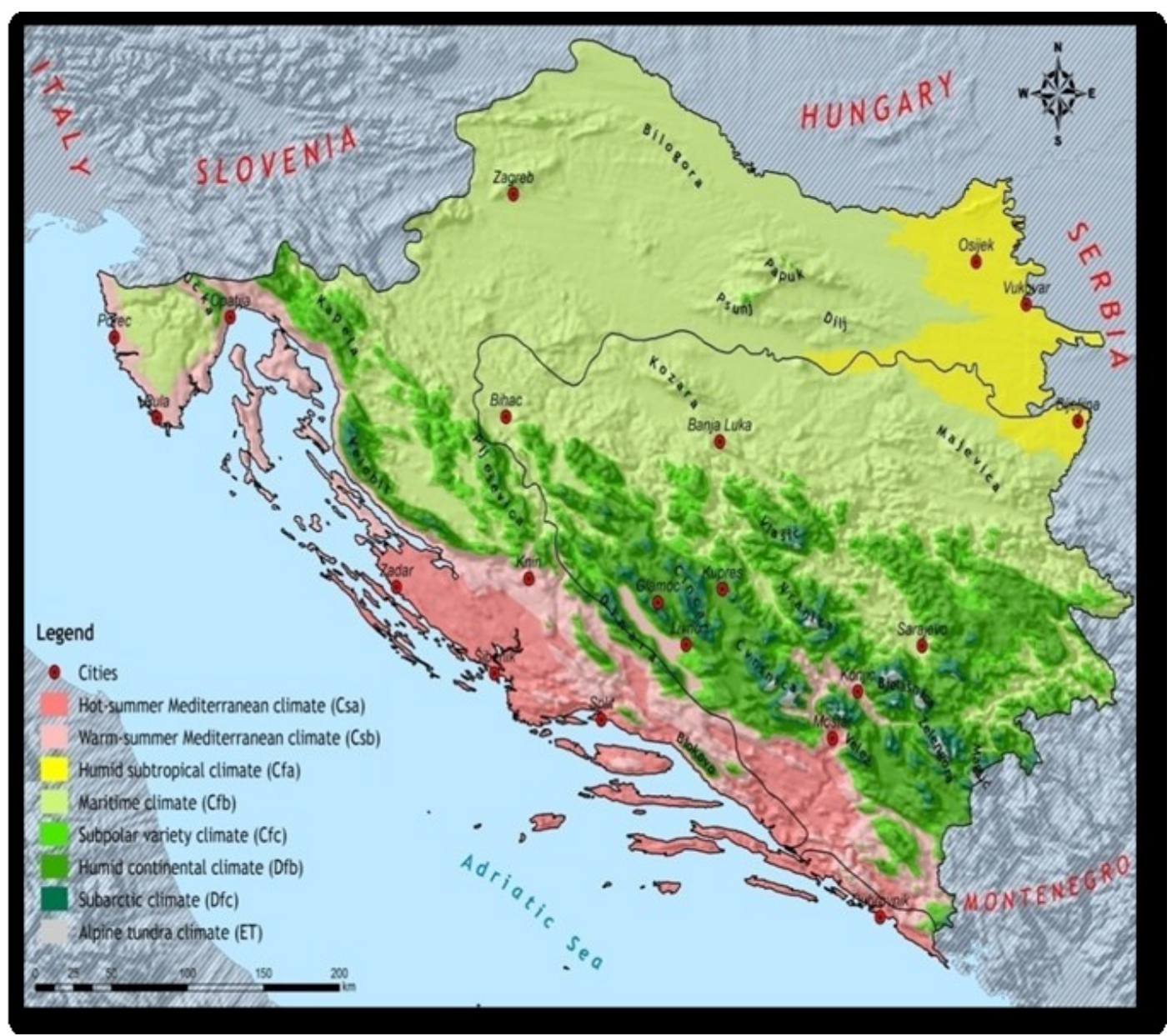

Fig.1 Distribution of Köppen Climate types in Bosnia\&Herzegovina and Croatia

\section{Antique period}

In the Antique period Diocletian's Palace has higher mark for the general tourist value than Basilica Cim because of better preservation and greater tourism importance. The preservation of those objects was influenced by wartime devastation and climatic factors, of which the most important are temperature fluctuations in deep inland.

\footnotetext{
${ }^{13}$ Košić, K. (2011) Tourist Evalutation [online], Faculty of Science, University of Novi Sad, Pages $3,7,11-13,21$
} 
Tab. 1. Tourist evaluation of the significant monuments of Antique origin

\begin{tabular}{|c|c|c|c|c|c|c|c|c|c|c|}
\hline$\sum^{\circ}$ & 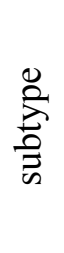 & City/Town & Monument & 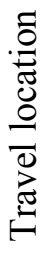 & 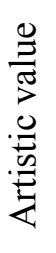 & 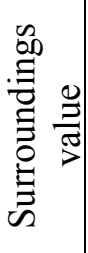 & 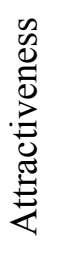 & 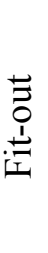 & 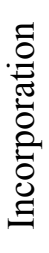 & 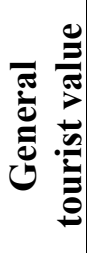 \\
\hline \multirow{3}{*}{$\mathrm{Cs}$} & \multirow[t]{2}{*}{ Csa } & Split & $\begin{array}{l}\text { Diocletian's } \\
\text { Palace }\end{array}$ & 5 & 5 & 5 & 5 & 4 & 5 & 4,8 \\
\hline & & Mostar & Basilica Cim & 4 & 3 & 4 & 2 & 4 & 4 & 3,5 \\
\hline & Csb & Pula & Pula Arena & 5 & 4 & 5 & 5 & 4 & 5 & 4,7 \\
\hline
\end{tabular}

\section{Byzantine period}

Although the monuments are situated in areas with different climate types, these objects in Zadar and Poreč have the high mark for general tourist value, mostly due to their artistic and surroundings values. Inter alia, their attractiveness is in fact that they were built in specific way, by using traditional building materials.

Tab. 2. Tourist evaluation of the significant Byzantine monuments

\begin{tabular}{|c|c|c|c|c|c|c|c|c|c|c|}
\hline 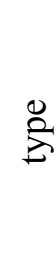 & $\begin{array}{l}\sum_{0}^{\circ} \\
\text { 苛 }\end{array}$ & City/Town & Monument & 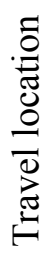 & 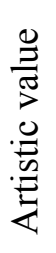 & 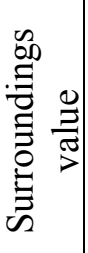 & 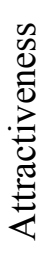 & 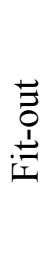 & 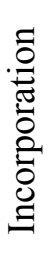 & 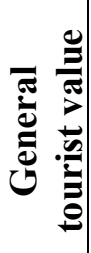 \\
\hline \multirow{2}{*}{$\mathrm{Cs}$} & Csa & Zadar & $\begin{array}{l}\text { Church of Saint } \\
\text { Donatus }\end{array}$ & 4 & 5 & 5 & 5 & 4 & 5 & 4,7 \\
\hline & Csb & Poreč & $\begin{array}{l}\text { Euphrasian } \\
\text { basilica }\end{array}$ & 4 & 5 & 5 & 5 & 3 & 5 & 4,5 \\
\hline
\end{tabular}

\section{Medieval period}

Banja Luka in $\mathrm{Cfb}$ climate type and Knin in the areas with Csb climate type have representative monuments of the national tourism significance, and those monuments include medieval fortresses which were built due to strategic importance. Those monuments still have the lower marks of general tourist value than the monuments in Zagreb and Dubrovnik, mainly because of their poor travel location and fit-outs. 
Tab. 3. Tourist evaluation of the significant Medieval monuments

\begin{tabular}{|c|c|c|c|c|c|c|c|c|c|c|}
\hline 总 & $\begin{array}{l}\text { 芯 } \\
\text { 泀 }\end{array}$ & City/Town & Monument & 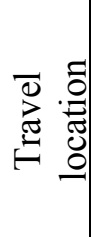 & 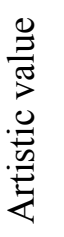 & 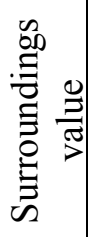 & 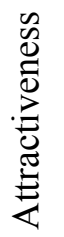 & 言 & 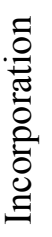 & 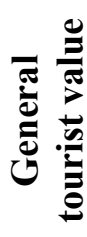 \\
\hline \multirow{3}{*}{$\mathrm{Cf}$} & \multirow{3}{*}{$\mathrm{Cfb}$} & $\begin{array}{l}\text { Banja } \\
\text { Luka }\end{array}$ & Kastel Fortress & 4 & 4 & 5 & 3 & 4 & 5 & 4,2 \\
\hline & & \multirow[b]{2}{*}{ Zagreb } & $\begin{array}{l}\text { Medvedgrad } \\
\text { Fortress }\end{array}$ & 4 & 5 & 5 & 4 & 5 & 4 & 4,5 \\
\hline & & & $\begin{array}{l}\text { Saint Mark's } \\
\text { Church }\end{array}$ & 5 & 5 & 5 & 5 & 5 & 5 & 5,0 \\
\hline \multirow[t]{2}{*}{ Cs } & Csa & Dubrovnik & $\begin{array}{l}\text { City walls with } \\
\text { forts }\end{array}$ & 5 & 5 & 5 & 5 & 5 & 5 & 5,0 \\
\hline & Csb & Knin & Knin Fortress & 4 & 4 & 5 & 4 & 3 & 5 & 4,2 \\
\hline
\end{tabular}

\section{Venetian period}

The most numerous monuments of the Venetian origin are located in the areas with Csa climate type and sometimes in the areas with Csb climate type. Those monuments are best evaluated (international tourism significance) especially due to their preservance and specific architecture style. Because of climatic conditions those monuments were built mostly of local stone.

Tab. 4. Tourist evaluation of the significant monuments of Venetian origin

\begin{tabular}{|c|c|c|c|c|c|c|c|c|c|c|}
\hline 芝 & $\sum_{\substack{0 \\
:}}^{0}$ & City/Town & Monument & 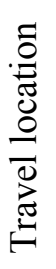 & 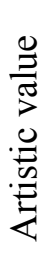 & 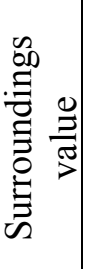 & 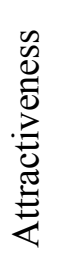 & 言 & 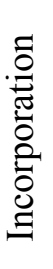 & 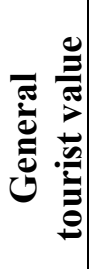 \\
\hline \multirow{4}{*}{ Cs } & \multirow{3}{*}{ Csa } & Šibenik & $\begin{array}{l}\text { Cathedral of } \\
\text { Saint James }\end{array}$ & 4 & 5 & 5 & 5 & 4 & 5 & 4,7 \\
\hline & & Dubrovnik & Sponza Palace & 5 & 5 & 5 & 5 & 5 & 5 & 5,0 \\
\hline & & Zadar & $\begin{array}{l}\text { Cathedral of } \\
\text { Saint Anastasia }\end{array}$ & 4 & 5 & 5 & 5 & 4 & 5 & 4,7 \\
\hline & $\mathrm{Csb}$ & Pula & Castle or Kaštel & 5 & 4 & 5 & 4 & 4 & 5 & 4,5 \\
\hline
\end{tabular}




\section{Ottoman period}

Monuments of the Ottoman origin are widespread in the areas of all climate types, where the cities with Ottoman cultural features are located. The least preserved monuments are in the areas with Dfb climate type due to more significant influence of continental landmass (greater temperature fluctuations and significant impacts of precipitation - mostly snow and ice). In the areas with $\mathrm{Csb}$ climate type monuments of national tourism significance exist and their preservance depends on the more significant influence of continental landmass as well as on the travel location and fit-outs. National tourism significance have monuments in Bijeljina, which marks are slightly lower due to a weaker surroundings and fit-out values. The best evaluated monuments of Ottoman origin are located in the areas with Csa and Csb climate types (Mostar and Sarajevo).

Tab. 5. Tourist evaluation of the significant monuments of Ottoman origin

\begin{tabular}{|c|c|c|c|c|c|c|c|c|c|c|}
\hline$\sum^{\circledR}$ & $\sum_{\frac{0}{2}}^{\infty}$ & City/Town & Monument & 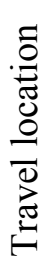 & 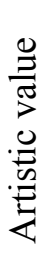 & 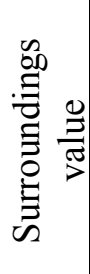 & 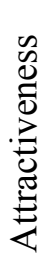 & 泀 & 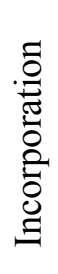 & 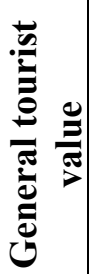 \\
\hline \multirow{6}{*}{$\mathrm{Cf}$} & \multirow[b]{2}{*}{ Cfa } & \multirow[b]{2}{*}{ Bijeljina } & Atik mosque & 4 & 4 & 3 & 4 & 3 & 4 & 3,7 \\
\hline & & & $\begin{array}{l}\text { Saint Georgije's } \\
\text { church }\end{array}$ & 4 & 5 & 3 & 4 & 3 & 4 & 3,8 \\
\hline & \multirow{4}{*}{$\mathrm{Cfb}$} & \multirow{3}{*}{ Sarajevo } & $\begin{array}{l}\text { Baščaršija old } \\
\text { town }\end{array}$ & 5 & 5 & 5 & 5 & 5 & 5 & 5,0 \\
\hline & & & $\begin{array}{l}\text { Ghazi Husrev- } \\
\text { Bey's mosque }\end{array}$ & 5 & 5 & 5 & 5 & 5 & 5 & 5,0 \\
\hline & & & Svrzo's house & 5 & 5 & 4 & 5 & 5 & 5 & 4,8 \\
\hline & & $\begin{array}{l}\text { Banja } \\
\text { Luka }\end{array}$ & $\begin{array}{l}\text { Ferhadija } \\
\text { mosque }\end{array}$ & 4 & 4 & 5 & 5 & 4 & 5 & 4,5 \\
\hline \multirow{5}{*}{ Cs } & Csa & Mostar & $\begin{array}{l}\text { The Old Bridge } \\
\text { area }\end{array}$ & 4 & 5 & 5 & 5 & 4 & 5 & 4,7 \\
\hline & \multirow{4}{*}{$\mathrm{Csb}$} & \multirow{3}{*}{ Livno } & $\begin{array}{l}\text { Hajji Ahmet } \\
\text { Dukatar mosque }\end{array}$ & 3 & 5 & 5 & 5 & 3 & 4 & 4,2 \\
\hline & & & $\begin{array}{l}\text { Bali-aga } \\
\text { Ljubunčić } \\
\text { mosque }\end{array}$ & 3 & 4 & 4 & 5 & 3 & 4 & 3,8 \\
\hline & & & $\begin{array}{l}\text { Monastery } \\
\text { church in Gorica }\end{array}$ & 3 & 5 & 5 & 5 & 3 & 5 & 4,3 \\
\hline & & Konjic & Old bridge & 3 & 5 & 5 & 5 & 3 & 4 & 4,2 \\
\hline Df & Dfb & Glamoč & $\begin{array}{l}\text { Old fortified } \\
\text { town Glamoč }\end{array}$ & 2 & 3 & 5 & 3 & 1 & 2 & 2,7 \\
\hline
\end{tabular}




\section{Austro-Hungarian period}

Tab. 6. Tourist evaluation of the significant monuments of Austro-Hungarian origin

\begin{tabular}{|c|c|c|c|c|c|c|c|c|c|c|}
\hline 芆 & 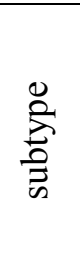 & City/Town & Monument & 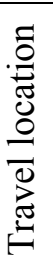 & 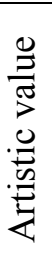 & 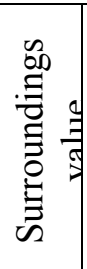 & 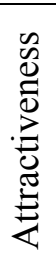 & 言 & 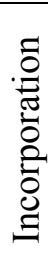 & . \\
\hline \multirow{3}{*}{$\mathrm{C}$} & \multirow{2}{*}{ Csa } & Mostar & High School building & 4 & 5 & 4 & 5 & 4 & 4 & 4,3 \\
\hline & & Dubrovnik & Hilton Imperial Hotel & 5 & 5 & 5 & 5 & 5 & 5 & $\mathbf{5 , 0}$ \\
\hline & Csb & Opatija & Kvarner Hotel & 4 & 5 & 4 & 5 & 4 & 5 & 4,5 \\
\hline \multirow{15}{*}{$\mathrm{Cf}$} & \multirow{7}{*}{$\mathrm{Cfa}$} & \multirow{2}{*}{ Osijek } & $\begin{array}{l}\text { Fortified town of } \\
\text { Osječka Tvrđa }\end{array}$ & 5 & 4 & 4 & 5 & 4 & 5 & 4,5 \\
\hline & & & $\begin{array}{l}\text { Counts Pejačević } \\
\text { Palace }\end{array}$ & 5 & 4 & 4 & 4 & 4 & 5 & 4,3 \\
\hline & & \multirow{3}{*}{ Vukovar } & $\begin{array}{l}\text { Historical Baroque } \\
\text { City center }\end{array}$ & 5 & 5 & 5 & 5 & 3 & 5 & 4,7 \\
\hline & & & Castle Eltz & 5 & 5 & 5 & 4 & 3 & 5 & 4,5 \\
\hline & & & $\begin{array}{l}\text { Church of Saints Filip } \\
\text { and Jakov and the } \\
\text { Monastery }\end{array}$ & 5 & 5 & 5 & 4 & 3 & 5 & 4,5 \\
\hline & & \multirow{2}{*}{ Bijeljina } & $\begin{array}{l}\text { Old High School } \\
\text { building }\end{array}$ & 4 & 3 & 4 & 3 & 4 & 5 & 3,8 \\
\hline & & & $\begin{array}{l}\text { Building of the } \\
\text { Assembly of the City }\end{array}$ & 4 & 5 & 4 & 4 & 4 & 5 & 4,3 \\
\hline & \multirow{8}{*}{$\mathrm{Cfb}$} & \multirow{3}{*}{ Sarajevo } & City Hall & 5 & 5 & 5 & 5 & 5 & 5 & $\mathbf{5 , 0}$ \\
\hline & & & $\begin{array}{l}\text { Sarajevo Academy of } \\
\text { fine arts }\end{array}$ & 5 & 5 & 5 & 5 & 5 & 5 & 5,0 \\
\hline & & & $\begin{array}{l}\text { National museum of } \\
\text { Bosnia\&Herzegovina }\end{array}$ & 5 & 5 & 4 & 5 & 5 & 5 & 4,8 \\
\hline & & \multirow[b]{2}{*}{$\begin{array}{l}\text { Banja } \\
\text { Luka }\end{array}$} & Mariastern Abbey & 4 & 5 & 4 & 4 & 4 & 5 & 4,3 \\
\hline & & & $\begin{array}{l}\text { Museum of modern } \\
\text { art of Republika } \\
\text { Srpska }\end{array}$ & 4 & 5 & 5 & 4 & 4 & 5 & 4,5 \\
\hline & & \multirow{3}{*}{ Zagreb } & Ilica street & 5 & 5 & 5 & 5 & 5 & 5 & $\mathbf{5 , 0}$ \\
\hline & & & $\begin{array}{l}\text { Croatian National } \\
\text { theater }\end{array}$ & 5 & 5 & 5 & 5 & 5 & 5 & 5,0 \\
\hline & & & Palace Hotel & 5 & 5 & 5 & 5 & 5 & 5 & 5,0 \\
\hline
\end{tabular}

The numerous monuments in the areas with $\mathrm{Cf}$ and Cs climates have been built in AustroHungarian period. Those monuments were mainly built of local materials, respecting their surroundings and natural environment. Monuments' marks of the general tourist value are ranging from national (Osijek, Banja Luka, Bijeljina and Mostar) to international (Sarajevo, Zagreb, Dubrovnik, Opatija and Vukovar) tourism significance. The most 
numerous among them are monuments in the areas with $\mathrm{Cfb}$ climate type (Sarajevo, Banja Luka and Zagreb) where the climatic conditions have been optimal for their construction.

\section{CONCLUSION}

In the areas of Bosnia\&Herzegovina and Croatia several climate types can be distinguished, and these types have specific natural and geographic features which have influenced different architecture styles. The largest area coverage has $\mathrm{Cfb}$ climate type, which also has the most diverse architecture styles. Temperate climate elements have caused that, most of all the air temperature and precipitation. Contrary to $\mathrm{Cfa}$ and $\mathrm{Cfb}$ climate types there are Csa and Csb climate types with much more extreme conditions, where the precipitation is unevenly distributed, while the average air temperatures are much higher than those temperatures in the areas with $\mathrm{Cf}$ climate. The natural barrier between these types is Dinaric Alps mountain range, with the most dominant D and E climates. This paper's object of study include urban architecture objects which, depending on the evaluation of the general tourist value, are considered as tourist attractions or resources. Generally if climate types were only observed regardless of the historical period of the monuments' origin, it can be said that monuments in the areas with Csa and Csb climate types have the greatest tourism significance. The reason for this also lies in the fact that most of the cities are located there, because of the optimal climatic conditions.

Monuments were categorised according to the most important historical periods: Antique, Byzantine, Medieval, Venetian, Ottoman and Austro-Hungarian. On average, the highest evaluation marks have monuments of Venetian origin $(4,5$ to 5,0), followed by Byzantine monuments (4,5 to 4,7), Medieval monuments $(4,2$ to 5,0$)$, monuments of Antique origin $(3,5$ to 4,8$)$, monuments of Austro-Hungarian origin $(3,8$ to 5,0$)$ and Ottoman monuments $(2,7$ to 5,0$)$. It can be said that usage of the building materials depends on the climatic conditions, especially the dominant usage of certain materials which depends on the average air temperatures, the type and amount of precipitation, the frequency of winds and geologic structure of certain area. For example, in the areas with Cs climates due to higher air temperatures and stronger winds, the most dominant building material is the stone, while in the areas with Dfb climate type the wood is mostly used as building material. However, in addition to climatic factors historical events in the past should not been excluded, because of their significant impact on the look and preservance of certain monuments. For example, the border zones between Venetian Republic and Ottoman Empire influence, or between Ottoman and Austro-Hungarian Empires, were often war zones in the past, so monuments in these zones are less preserved than in the areas that had been safer like the areas in deeper inland or on the Adriatic coast which were guarded well, hence there are located the most important historical monuments which have national or international tourism significance.

\section{REFERENCES}

1. https://atlas.media.mit.edu/en/profile/country/bih/ (19.08.2015.)

2. https://atlas.media.mit.edu/en/profile/country/hrv/ (19.08.2015.)

3. http://whc.unesco.org/en/list/ (21.08.2015.)

4. http://www.visitsplit.com/en/446/attractions (24.08.2015.)

5. Dubrovnik Tourist Board (2013) Dubrovnik Riviera Info, Alfa-2. Dubrovnik 
6. Burek, A. (2007) Kameno Hlivno, Livno u turskom vaktu (Stone Hlivno, Livno in the Ottoman time), Planjax. Tešanj

7. Istria Tourist Board (2015) Enjoy Istra summer 2015, Radin Print. Sveta Nedelja

8. http://www.turizamvukovar.hr/vukovar_eng.php?stranica=171 (23.08.2015.)

9. Zagreb Tourist Board (2015) Step by step Zagreb: A walk through Zagreb, Kerschoffset. Zagreb

10. Košić, K. (2011, April). Tourist Evaluation - Definition, Purpose and Elements, Faculty of Science, University of Novi Sad, Retrieved from http://www.dgt.uns.ac.rs/download/otv1.pdf (25.08.2015.) 